\title{
In type 2 diabetes, randomisation to advice to follow a low-carbohydrate diet transiently improves glycaemic control compared with advice to follow a low-fat diet producing a similar weight loss
}

\author{
H. Guldbrand • B. Dizdar • B. Bunjaku • T. Lindström • \\ M. Bachrach-Lindström • M. Fredrikson • \\ C. J. Östgren • F. H. Nystrom
}

Received: 2 April 2012 /Accepted: 4 April 2012 /Published online: 6 May 2012

(C) The Author(s) 2012. This article is published with open access at Springerlink.com

\begin{abstract}
Aims/hypothesis The study aimed to compare the effects of a 2 year intervention with a low-fat diet (LFD) or a lowcarbohydrate diet (LCD), based on four group meetings to achieve compliance.

Methods This was a prospective randomised parallel trial involving 61 adults with type 2 diabetes consecutively recruited in primary care and randomised by drawing ballots. Patients that did not speak Swedish could not be recruited. The primary outcomes in this non-blinded study were weight and $\mathrm{HbA}_{1 \mathrm{c}}$. Patients on the LFD aimed for 55-60 energy per cent $(\mathrm{E} \%)$ and those on LCD for $20 \mathrm{E} \%$ from carbohydrate. Results The mean $\mathrm{BMI}$ and $\mathrm{HbA}_{1 \mathrm{c}}$ of the participants were $32.7 \pm 5.4 \mathrm{~kg} / \mathrm{m}^{2}$ and $57.0 \pm 9.2 \mathrm{mmol} / \mathrm{mol}$, respectively. No patients were lost to follow-up. Weight loss did not differ between groups and was maximal at 6 months: LFD $-3.99 \pm$ $4.1 \mathrm{~kg}(n=31) ; \mathrm{LCD}-4.31 \pm 3.6 \mathrm{~kg}(n=30) ; p<0.001$ within
\end{abstract}

Electronic supplementary material The online version of this article (doi:10.1007/s00125-012-2567-4) contains peer-reviewed but unedited supplementary material, which is available to authorised users.

H. Guldbrand $(\bowtie) \cdot$ B. Dizdar $\cdot$ B. Bunjaku $\cdot$ T. Lindström $\cdot$

M. Bachrach-Lindström • C. J. Östgren · F. H. Nystrom

Department of Medical and Health Sciences, Faculty of Health

Science, Linköping University,

SE 58185 Linköping, Sweden

e-mail: hans.guldbrand@lio.se

T. Lindström • C. J. Östgren · F. H. Nystrom

Diabetes Research Centre,

Faculty of Health Science, Linköping University,

Linköping, Sweden

M. Fredrikson

Department of Clinical and Experimental Medicine,

Faculty of Health Science, Linköping University,

Linköping, Sweden groups. At 24 months, patients on the LFD had lost $-2.97 \pm$ $4.9 \mathrm{~kg}$ and those on LCD $-2.34 \pm 5.1 \mathrm{~kg}$ compared with baseline ( $p=0.002$ and $p=0.020$ within groups, respectively). $\mathrm{HbA}_{1 \mathrm{c}}$ fell in the LCD group only (LCD at 6 months $-4.8 \pm$ $8.3 \mathrm{mmol} / \mathrm{mol}, p=0.004$, at $12 \mathrm{months}-2.2 \pm 7.7 \mathrm{mmol} / \mathrm{mol}$, $p=0.12$; LFD at 6 months $-0.9 \pm 8.8 \mathrm{mmol} / \mathrm{mol}, p=0.56$ ). At 6 months, HDL-cholesterol had increased with the LCD (from $1.13 \pm 0.33 \mathrm{mmol} / 1$ to $1.25 \pm 0.47 \mathrm{mmol} / 1, p=0.018$ ) while LDL-cholesterol did not differ between groups. Insulin doses were reduced in the LCD group (0 months, LCD $42 \pm 65 \mathrm{E}$, LFD $39 \pm 51$ E; 6 months, LCD $30 \pm 47$ E, LFD $38 \pm 48$ E; $p=0.046$ for between-group change).

Conclusions/interpretation Weight changes did not differ between the diet groups, while insulin doses were reduced significantly more with the LCD at 6 months, when compliance was good. Thus, aiming for $20 \%$ of energy intake from carbohydrates is safe with respect to cardiovascular risk compared with the traditional LFD and this approach could constitute a treatment alternative.

Trial registration: ClinicalTrials.gov NCT01005498 Funding: University Hospital of Linköping Research Funds, Linköping University, the County Council of Östergötland, and the Diabetes Research Centre of Linköping University

Keywords Blood glucose · Dietary intervention .

HDL-cholesterol - LDL-cholesterol - Low-carbohydrate diet . Type 2 diabetes
Abbreviations
E\% Energy per cent
LCD Low-carbohydrate diet
LFD Low-fat diet 


\section{Introduction}

The prevalence of type 2 diabetes is increasing worldwide, and this is likely to be a consequence of the increasing prevalence of obesity. Weight loss in obesity generally leads to improvement in cardiovascular risk factors and glycaemic control $[1,2]$. However, few randomised studies have specifically targeted type 2 diabetes to compare the effect of different diets in this respect. Traditionally, a low-fat diet (LFD) has been recommended [3] to patients with type 2 diabetes as a means to lose weight and, in particular, a low intake of saturated fat has been advocated $[4,5]$. Interestingly, in a randomised 2 year study from Israel that achieved good compliance, a high-fat diet was shown to induce better weight reduction and improved blood lipid levels than a traditional LFD in obese participants, while the subgroup of patients with diabetes who were randomised to the highfat diet exhibited the largest reduction in $\mathrm{HbA}_{1 \mathrm{c}}$ levels [6].

From a physiological point of view it could be argued that carbohydrate should be avoided to achieve good glycaemic control in type 2 diabetes, as a typical feature of type 2 diabetes is the combination of reduced insulin sensitivity and the failure of beta cells to provide adequate amounts of insulin to handle glucose derived from carbohydrate in the diet. However, when the macronutrient composition is changed in a diet by reducing carbohydrate, the energy from this source is primarily replaced by that from fat, as a high energy intake from protein is hard to achieve in the long term. Thus, a low-carbohydrate diet (LCD) is quite similar to one with a high intake of fat, which has traditionally been linked with increased risk for arteriosclerosis, particularly when large amounts of saturated fat are consumed. However, recent data have challenged the concept of the risks with a high-fat diet. In a Swedish observational study in 28,000 middle-aged individuals, neither a high fat intake nor an intake of large amounts of saturated fat (22 E\%) was linked with an increased risk for cardiovascular disease [7, 8].

Most earlier studies examining high-fat diets in patients with type 2 diabetes have had limitations, such as a high dropout frequency [9-12], lack of randomisation [13-15], or a maximum duration of 12 months [11, 12, 16]. Another problem for the clinical feasibility of studies involving patients with type 2 diabetes has been the scale of the resources necessary to achieve compliance with the tested diets; typically, numerous individual meetings with trained dietitians are held during the studies [11, 16, 17]. If these measures were to become part of routine healthcare for such a common disease, there would be considerable economic implications for the medical provider.

We performed a randomised study in patients with type 2 diabetes to compare glycaemic control, weight loss and cardiovascular risk factors based on the advice of a lowcarbohydrate or a traditional LFD. In contrast to most previous studies, the patients randomised to the LCD were not asked to avoid saturated fat. The interventions were based on four group meetings with a duration of $60 \mathrm{~min}$ each for the first year; no further group meetings during the remaining 12 months were held. Our hypothesis was that the high-fat diet would improve glycaemic control more efficiently than the traditional LFD in a study in which few resources were allocated for achieving compliance, so that clinical use of the protocol would be realistic for many providers of care.

\section{Methods}

The study was conducted in two primary healthcare centres in the cities of Motala and Borensberg, located in southeast Sweden. Patients who fulfilled the criteria for participation were contacted individually by one of three study nurses. The nurses had also been responsible for the care of these potential participants ahead of the study start. The inclusion criteria were a diagnosis of type 2 diabetes treated with diet with or without additional oral glucose-lowering medication, incretin-based therapy or insulin. There were no weight or age exclusion criteria, but patients who had difficulties understanding the Swedish language, were suffering from severe mental disease or malignant disease, or who were abusing drugs could not participate in the study.

The patients were randomised to either an LCD or a traditional LFD, both with an energy content of $6,694 \mathrm{~kJ} /$ day $(1,600 \mathrm{kcal} /$ day $)$ for women or $7,531 \mathrm{~kJ} /$ day $(1,800 \mathrm{kcal} /$ day $)$ for men. Randomisation was not stratified and was based on drawing blinded ballots. The LCD had an energy content where 50 energy per cent (E\%) was from fat, $20 \mathrm{E} \%$ was from carbohydrate and $30 \mathrm{E} \%$ was from protein. The LFD had a nutrient composition that was similar to that traditionally recommended for the treatment of type 2 diabetes in Sweden, with $30 \mathrm{E} \%$ from fat (less than $10 \mathrm{E} \%$ from saturated fat), 55 $60 \mathrm{E} \%$ from carbohydrate and 10-15 E\% from protein.

Group information was used to inform the randomised patients about which food items to choose from, and this was given at baseline, and 2, 6 and 12 months by two different physicians. One dedicated dietitian provided the participants from both groups with suitable recipes at each group meeting, and was also available consecutively during the trial for questions from the participants. However, all the information necessary was provided at the group information meetings, and thus no individual meetings with the dietitian were scheduled as part of the general protocol. Menus for 1 week were provided to the participants as meal suggestions by the dietitian. Each patient had the same dedicated nurse during the whole study period and the nurses could also provide information about food to the patients during regular consultations. The patients were 
recommended to check plasma glucose levels before and after meals after initiation of the study to allow for proper adjustment of medication to avoid hypoglycaemia. No information was given to change the level of physical activity. As the duration of the trial was 2 years, and because individuals with high risk for cardiovascular events were recruited, it was judged to be unethical not to be allowed to adjust medication to avoid cardiovascular disease in the study. The physician responsible for each patient at the primary healthcare centre was thus allowed to adjust hypolipidaemic and antihypertensive medications consecutively in the trial.

Investigations of anthropometrics and laboratory tests were performed at baseline and at 6,12 and 24 months, and patients were also asked to fill out questionnaires of wellbeing at these time points. Diet records were also performed at these four visits, with one additional recording at 3 months. The diet records were conducted during 3 consecutive days, of which 1 day was a Saturday or a Sunday. The participants were provided with dedicated scales and notebooks from the organisers with which to weigh and record all food items that were consumed during these periods (food frequency questionnaires were not used). Sagittal abdominal diameter was measured with a sliding beam set square as the highest abdominal level above the upper surface of the corresponding bed. The laboratory tests were analysed at the Department of Clinical Chemistry at the University Hospital of Linköping as part of clinical routine analyses, and fasting LDL-cholesterol was thus calculated using the Friedewald formula.

Statistics Statistical calculations were made using PASW 18.0 software (SPSS, Chicago, IL, USA). Linear correlations were calculated as stated in the text. Comparisons within and between groups were made with Student's paired and unpaired two-tailed $t$ tests or as stated in the results section. The mean (SD) is given unless otherwise stated. Statistical significance was considered to be present at the $5 \%$ level $(p \leq 0.05)$. ANOVA with repeated measures was used for calculations of the changes during the total duration of the study.

The size of the study was based on an earlier 6 month pilot study of 28 participants with type 2 diabetes who were randomised to the same diets as in the study presented in this paper. Twenty individuals completed the pilot study and both diet groups achieved similar weight reductions, while $\mathrm{HbA}_{1 \mathrm{c}}$ levels tended to be lowered in the low-carbohydrate group only, without taking change in medication into account (low carbohydrate, $p=0.068$; low-fat group, $p=0.8$ ). Based on these results, the study sample was increased to at least 30 individuals in each group in the present study. None of the participants in the pilot study participated in the trial presented in this paper. The study duration of 24 months was requested by the Regional Ethics Committee of Linköping.
Ethical approval The study was approved by the Regional Ethics Committee of Linköping and performed in accordance with the Declaration of Helsinki. Written informed consent was obtained from all participating individuals. The study was registered with trial number NCT01005498 at ClinicalTrials.gov.

\section{Results}

Total study population The study nurses invited 72 consecutive patients to participate in the study from the autumn of 2008 to the start of the clinical trial in March 2009. Ten patients declined because they judged the study to be too timeconsuming and one patient believed that a high-fat diet might be hazardous. The remaining 61 patients entered the study, but three in the LFD group and four in the LCD group expressed that they had severe difficulty following the prescribed diets and were not willing to participate in the group meetings. Data on the main outcomes from these seven patients were used in statistical analyses according to intention-to-treat analysis (Table 1; see also Fig. 1 for flow diagram). In the low-fat group, the mean age was $62.7 \pm 11$ years, there were 13 men and 18 women and the mean duration of known diabetes was $8.8 \pm 6.2$ years. Corresponding figures for the low-carbohydrate group were $61.2 \pm 9.5$ years, 14 men and 16 women and a duration of known diabetes of $9.8 \pm 5.5$ years. Age, sex distribution and known duration of diabetes did not differ between the groups (all $p>0.5$ ). At baseline, two patients in the low-fat group and two in the low-carbohydrate group were treated with diet only, 13 in the low-fat group and 15 in the lowcarbohydrate group were using oral glucose-lowering medication only, and 11 in the low-fat group and 10 in the lowcarbohydrate group were treated with a combination of insulin and oral medication. At 24 months, 14 individuals (four in the LFD group and ten in the LCD group) did not provide diet records, but data on the main outcomes were used in calculations. The dietitian had individual consultations with four patients in the low-carbohydrate group and three patients in the low-fat group; information was otherwise only provided during the group meetings. These individual contacts all took part during the first 12 months of the study. Table 1 shows anthropometrics, laboratory variables and medication from baseline throughout the study. The recorded intake of energy from fat and carbohydrate differed between the groups (Table 2).

There was no difference in weight reduction between the groups at 6 months (LFD group $-4.0 \pm 4.1 \mathrm{~kg}$; LCD group $-4.3 \pm 3.6 \mathrm{~kg} ; p=0.75$ for difference in change between groups and $p<0.001$ within either group; Table 1 and Fig. 2). There were also no statistically significant differences in weight reduction between groups after adjustment for baseline carbohydrate or fat intake (all $p>0.5$ ). 


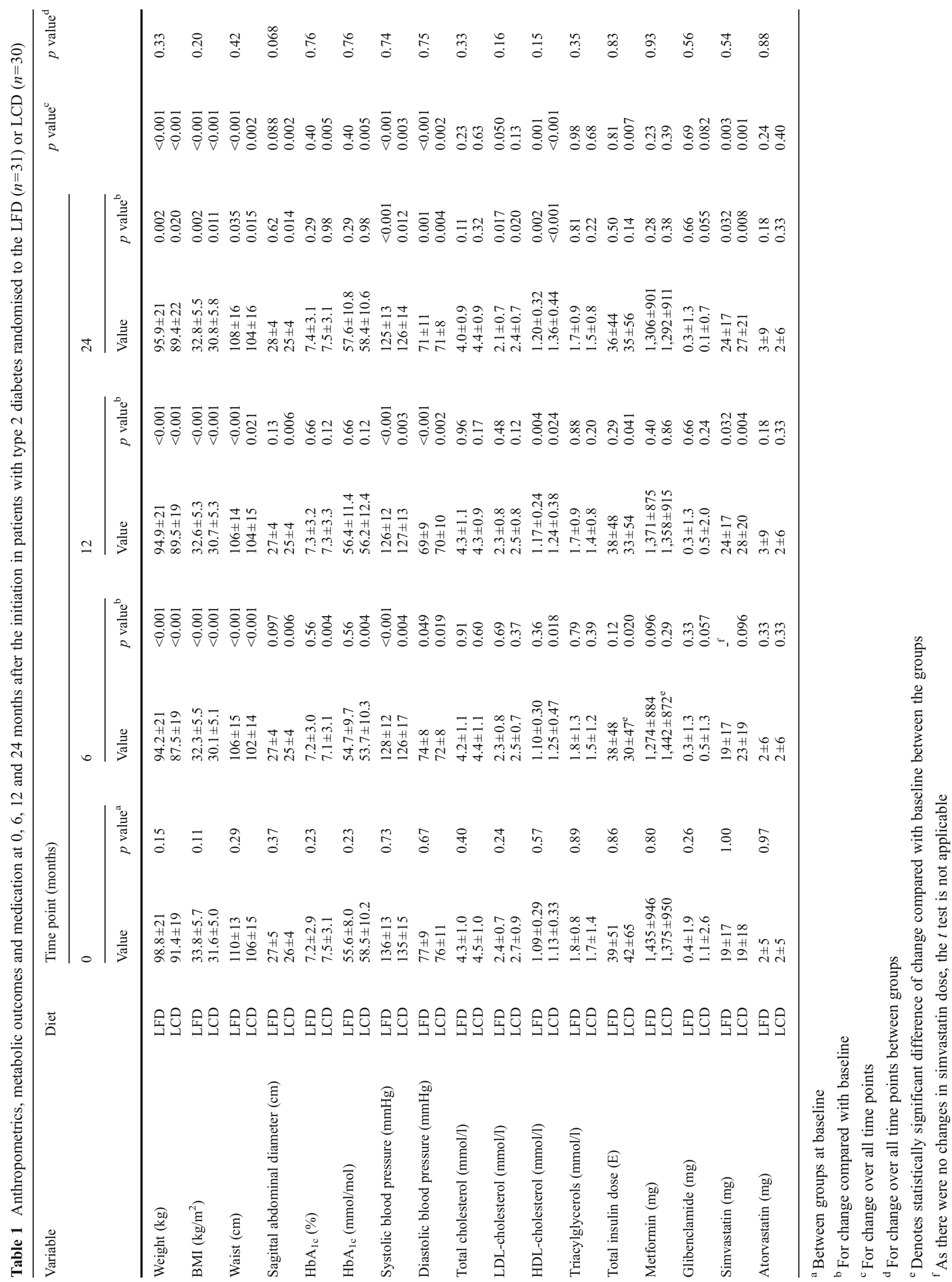


Fig. 1 Flow diagram of the study

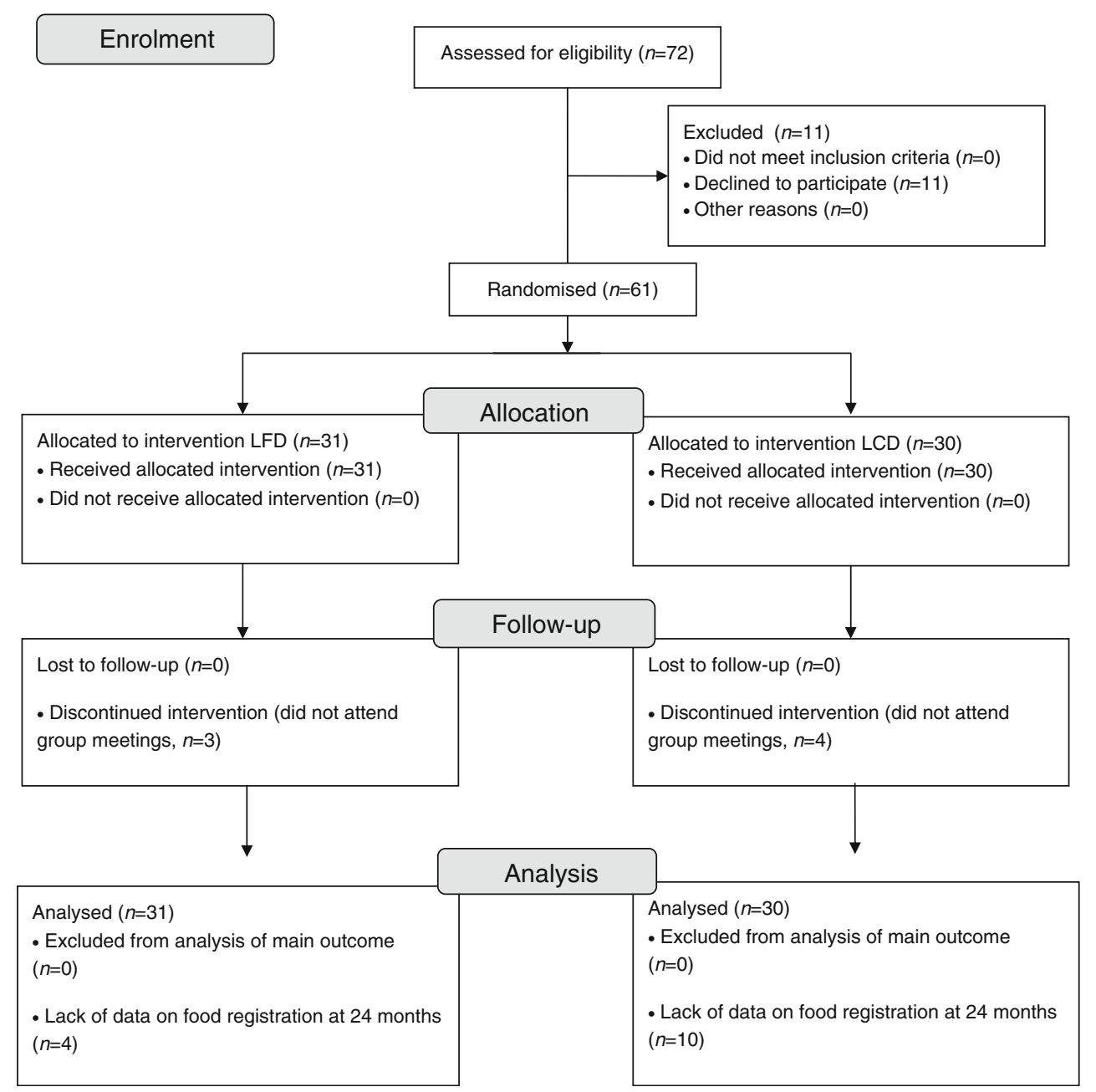

A significant reduction in $\mathrm{HbA}_{1 \mathrm{c}}$ was seen at 6 months in the low-carbohydrate group only (Table 1). However, $\mathrm{HbA}_{1 \mathrm{c}}$ levels gradually returned to baseline levels after 6 months as shown in Fig. 3 and Table 1. The change in $\mathrm{HbA}_{1 \mathrm{c}}$ level at 6 months compared with baseline was not statistically significant between the groups ( $p=0.089)$. Reductions in oral medication and insulin dose were made consecutively to avoid hypoglycaemia, and the reduction in insulin was statistically significant only in the low-carbohydrate group at 6 months (Table 1). This change in the average insulin dose was statistically significant between the two groups at 6 months $(p=0.046)$.

There were no significant differences between groups regarding office blood pressure levels in the study (Table 1). At 6 months, four patients in the LCD group and one patient in the LFD group had started on treatment with statins or had their former dose increased (see also Table 1). Corresponding figures for these medical adjustments during the entire study period were nine patients in the LCD group and seven patients receiving the LFD. By the end of the trial, 54 of 61 patients received lipid-lowering medication. At 6 months, the low-carbohydrate group showed significantly increased levels of HDL-cholesterol (Table 1; $p=0.018$ for change within group, $p=0.077$ for change between groups). No patient suffered cardiovascular disease or other serious adverse events during the study.

The results of the dietary records are shown in Table 2. During the first 6 months, adherence to the proposed diet was comparatively good in both groups as judged by mean values of macronutrient intake (Table 2). The low-fat group did not significantly change the macronutrient composition during the study, while there was an increase in energy from fat in those randomised to LCD (Table 2). Despite reduction of energy intake, total intake of fat showed no reduction in the low-carbohydrate group, which was in contrast to the low-fat group (Table 2). The percentage of energy intake from saturated fat increased in the low-carbohydrate group throughout the whole study, but there were no differences between the groups regarding energy intake, according to the diet records (Table 2).

Completers analysis Additional analyses were made according to compliance with energy intake. Table 3 shows results for only those patients who consumed $\leq 6,694 \mathrm{~kJ} /$ day 
Table 2 Dietary outcomes at 0,6,12 and 24 months after the initiation in patients with type 2 diabetes randomised to the LFD or LCD

\begin{tabular}{|c|c|c|c|c|c|c|c|c|c|}
\hline \multirow[t]{3}{*}{ Variable } & \multirow{3}{*}{$\begin{array}{l}0 \text { months } \\
n=61 \\
\text { Value }\end{array}$} & \multirow{2}{*}{\multicolumn{2}{|c|}{$\begin{array}{l}3-6 \text { months } \\
n=55\end{array}$}} & \multirow{2}{*}{\multicolumn{2}{|c|}{$\begin{array}{l}12 \text { months } \\
n=42\end{array}$}} & \multirow{2}{*}{\multicolumn{2}{|c|}{$\begin{array}{l}24 \text { months } \\
n=47\end{array}$}} & \multirow[t]{3}{*}{$p$ value $^{\mathrm{b}}$} & \multirow[t]{3}{*}{$p$ value $^{\mathrm{c}}$} \\
\hline & & & & & & & & & \\
\hline & & Value & $p$ value $^{\mathrm{a}}$ & Value & $p$ value $^{\mathrm{a}}$ & Value & $p$ value $^{\mathrm{a}}$ & & \\
\hline \multicolumn{10}{|c|}{ Energy intake (kJ) } \\
\hline LFD & $7,569 \pm 2,063$ & $6,498 \pm 1,787$ & 0.005 & $6,619 \pm 2,075$ & 0.075 & $6,104 \pm 1,891$ & 0.002 & 0.010 & \multirow[t]{2}{*}{0.065} \\
\hline $\mathrm{LCD}$ & $7,071 \pm 1,782$ & $5,791 \pm 1,531$ & $<0.001$ & $6,017 \pm 2,075$ & 0.037 & $5,234 \pm 1,799$ & $<0.001$ & $<0.001$ & \\
\hline \multicolumn{10}{|c|}{ Carbohydrate energy (\%) } \\
\hline LFD & $48 \pm 6$ & $49 \pm 6$ & 0.88 & $47 \pm 6$ & 0.38 & $47 \pm 7$ & 0.31 & 0.28 & \multirow[t]{2}{*}{$<0.001$} \\
\hline LCD & $41 \pm 11^{\mathrm{e}}$ & $25 \pm 8^{\mathrm{d}}$ & $<0.001$ & $27 \pm 8^{\mathrm{d}}$ & $<0.001$ & $31 \pm 6^{\mathrm{d}}$ & $<0.001$ & $<0.001$ & \\
\hline \multicolumn{10}{|c|}{ Fat energy $(\%)$} \\
\hline LFD & $32 \pm 5$ & $29 \pm 5$ & 0.12 & $31 \pm 6$ & 0.96 & $31 \pm 7$ & 0.87 & 0.28 & \multirow[t]{2}{*}{$<0.001$} \\
\hline LCD & $39 \pm 7^{\mathrm{e}}$ & $49 \pm 7^{\mathrm{d}}$ & $<0.001$ & $47 \pm 6^{\mathrm{d}}$ & $<0.001$ & $44 \pm 5^{\mathrm{d}}$ & $<0.001$ & $<0.001$ & \\
\hline \multicolumn{10}{|c|}{ Protein energy (\%) } \\
\hline LFD & $19 \pm 3$ & $21 \pm 3$ & 0.012 & $20 \pm 3$ & 0.044 & $20 \pm 2$ & 0.045 & 0.037 & \multirow[t]{2}{*}{0.009} \\
\hline LCD & $19 \pm 3$ & $24 \pm 3^{d}$ & $<0.001$ & $23 \pm 5^{\mathrm{d}}$ & 0.002 & $24 \pm 4^{d}$ & $<0.001$ & $<0.001$ & \\
\hline \multicolumn{10}{|c|}{ Alcohol energy (\%) } \\
\hline LFD & $1 \pm 2$ & $2 \pm 3$ & 0.23 & $2 \pm 3$ & 0.36 & $2 \pm 3$ & 0.27 & 0.72 & \multirow[t]{2}{*}{0.49} \\
\hline $\mathrm{LCD}$ & $2 \pm 4$ & $2 \pm 4$ & 0.83 & $2 \pm 3$ & 0.037 & $2 \pm 4$ & 0.79 & 0.018 & \\
\hline \multicolumn{10}{|c|}{ Total fat $(\mathrm{g})$} \\
\hline LFD & $66 \pm 23$ & $53 \pm 20$ & 0.014 & $56 \pm 23$ & 0.27 & $52 \pm 22$ & 0.007 & 0.11 & \multirow[t]{2}{*}{0.008} \\
\hline LCD & $74 \pm 23$ & $78 \pm 24^{\mathrm{d}}$ & 0.081 & $77 \pm 29$ & 0.22 & $63 \pm 24$ & 0.17 & 0.10 & \\
\hline \multicolumn{10}{|c|}{ Saturated fat energy $(\%)$} \\
\hline LFD & $13 \pm 3$ & $11 \pm 2$ & 0.090 & $12 \pm 3$ & 0.96 & $13 \pm 3$ & 0.61 & 0.20 & \multirow[t]{2}{*}{$<0.001$} \\
\hline LCD & $16 \pm 4$ & $20 \pm 4^{\mathrm{d}}$ & $<0.001$ & $20 \pm 4^{\mathrm{d}}$ & 0.008 & $19 \pm 2^{d}$ & $<0.001$ & $<0.001$ & \\
\hline \multicolumn{10}{|c|}{ Unsaturated fat energy (\%) } \\
\hline LFD & $12 \pm 2$ & $11 \pm 2$ & 0.20 & $11 \pm 2$ & 0.71 & $11 \pm 3$ & 0.50 & 0.80 & \multirow[t]{2}{*}{$<0.001$} \\
\hline LCD & $14 \pm 3$ & $18 \pm 3^{\mathrm{d}}$ & $<0.001$ & $17 \pm 3^{\mathrm{d}}$ & $<0.001$ & $16 \pm 3^{\mathrm{d}}$ & $<0.001$ & $<0.001$ & \\
\hline \multicolumn{10}{|c|}{ Polyunsaturated fat energy (\%) } \\
\hline LFD & $5 \pm 2$ & $5 \pm 2$ & 0.92 & $5 \pm 2$ & 0.97 & $5 \pm 2$ & 0.58 & 0.76 & \multirow[t]{2}{*}{0.001} \\
\hline LCD & $6 \pm 3$ & $8 \pm 2^{\mathrm{d}}$ & $<0.001$ & $8 \pm 2^{d}$ & 0.006 & $6 \pm 2$ & 0.044 & 0.002 & \\
\hline
\end{tabular}

Data are given for all participants who provided complete diet records

${ }^{\text {a }}$ Compared with baseline

${ }^{\mathrm{b}}$ For change over all time points

${ }^{\mathrm{c}}$ For change over all time points (between groups)

${ }^{d}$ Denotes statistically significant difference between changes in the two groups

${ }^{\mathrm{e}}$ Denotes statistically significant difference between groups at baseline

$(1,600 \mathrm{kcal} /$ day $)$ for women or $\leq 7,531 \mathrm{~kJ} /$ day $(1,800 \mathrm{kcal} /$ day) for men according to the last diet record at 24 months; it includes 17 patients in the low-fat group and 18 patients in the low-carbohydrate group. At 24 months the patients randomised to the LFD weighed $3.1 \pm 4.3 \mathrm{~kg}$ less than at baseline and the corresponding figure for the lowcarbohydrate group was $3.5 \pm 4.0 \mathrm{~kg}$. This suggests that, in particular, the high-fat group had lower compliance at this time point, which affected weight gain in the total LCD-cohort (i.e. $-3.5 \pm 4.0 \mathrm{~kg}$ in completers compared with $-2.3 \pm 5.1 \mathrm{~kg}$ in the total cohort). While sagittal abdominal diameter was stable in the low-fat group, this was reduced by $2 \mathrm{~cm}$ in the lowcarbohydrate group. However, the low-fat group with energy compliance had reduced systolic and diastolic blood pressure, effects lacking in those randomised to the high-fat diet (Table 3). A second completers analysis based on compliance with fat intake is available in the electronic supplementary material (ESM; compliance defined as: $\leq 35 \mathrm{E} \%$ from fat in the low-fat group, $n=20$, or $\geq 45 \mathrm{E} \%$ from fat for the lowcarbohydrate group, $n=12, \chi^{2}$ between groups for compliance with intake of fat $p=0.06$ ). Similar results to those in the completers analysis according to energy intake were found 


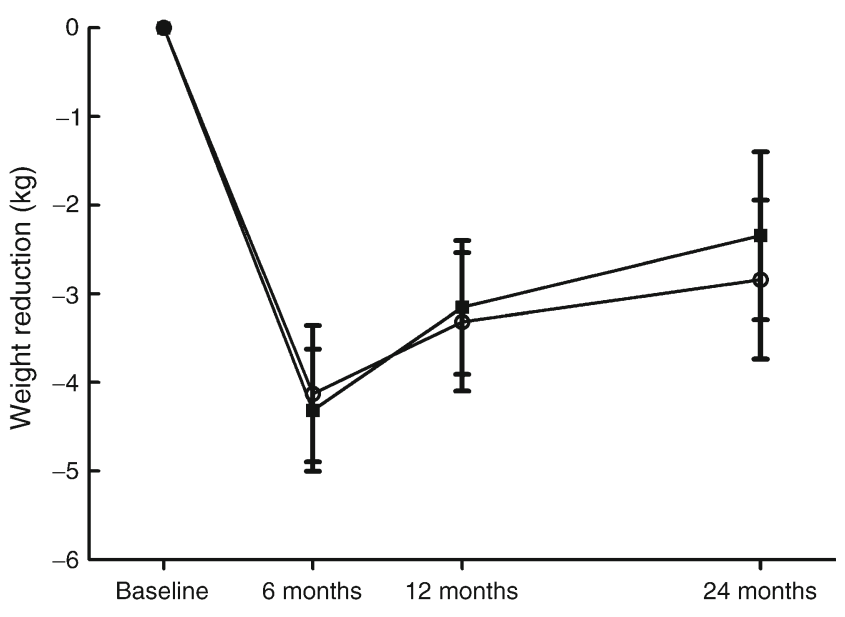

Fig. 2 Comparison of weight reduction with an LCD, aiming to achieve $20 \mathrm{E} \%$ from carbohydrate (squares), and an LFD (circles), aiming for 55-60 E\% from carbohydrates, during 2 years in patients with type 2 diabetes. The weight reduction did not differ between the groups ( $p=0.33$ for all time points)

in this post-hoc calculation for sagittal abdominal diameter and blood pressure. HDL-cholesterol increased from $1.11 \pm$ 0.36 to $1.46 \pm 0.59 \mathrm{mmol} / 1$ ( $p=0.001$ for all time points) in those compliant with the LCD according to fat intake, while corresponding figures for the LFD were $1.05 \pm 0.26 \mathrm{mmol} / \mathrm{l}$ at baseline to $1.17 \pm 0.25 \mathrm{mmol} / \mathrm{l}$ at 24 months $(p=0.006$ within group and $p=0.016$ for change between groups).

\section{Discussion}

Our study did not confirm the finding that weight reduction is more efficient in individuals following an LCD than in

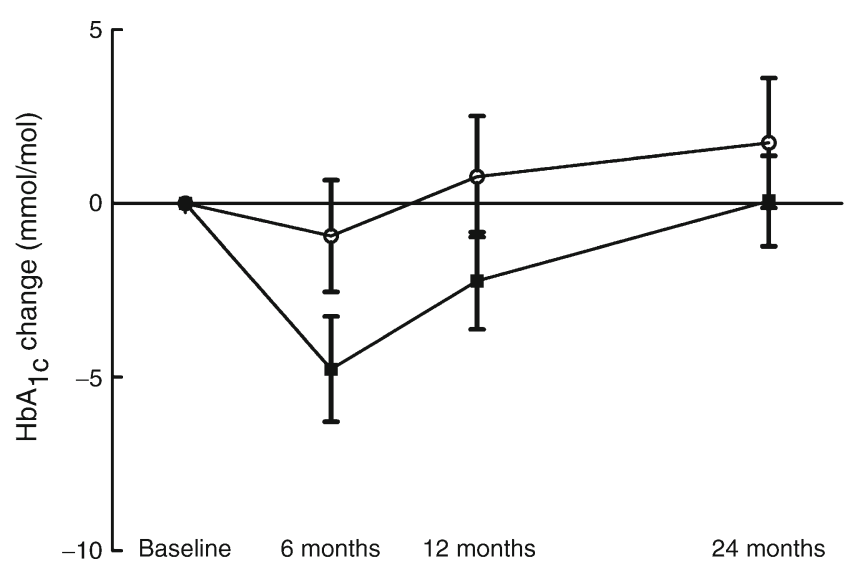

Fig. 3 Comparison of the reduction in $\mathrm{HbA}_{1 \mathrm{c}}$ levels following an $\mathrm{LCD}$ with the aim of achieving $20 \mathrm{E} \%$ from carbohydrate (squares), and an LFD (circles), aiming for 55-60 E\% from carbohydrate, over 2 years in patients with type 2 diabetes. The reduction in $\mathrm{HbA}_{1 \mathrm{c}}$ level was statistically significant within the low-carbohydrate group $(p=0.005$ for all time points), but did not differ between the groups when compared at all time points $(p=0.76)$. To convert values for $\mathrm{HbA}_{1 \mathrm{c}}$ in $\mathrm{mmol} / \mathrm{mol}$ into $\%$, divide by 10.929 and add 2.15 those following an LFD, as has been found in some previous trials $[6,9,12,18-20]$. An important difference in our study compared with these earlier studies [6, 9, 12, 18-20] was that we used comparatively fewer resources to achieve compliance. In our study, only four group meetings were offered during the first 12 months of the trial. The rationale for this design was to make the results more applicable to regular clinic care in which educational activities such as group meetings can be offered as a means to improve glycaemic control. No patients were lost to follow-up and data on glycaemic control were complete at 24 months, while data on weight were lacking for only one participant at this time point. This outcome of our study left minimal room for the selection of participants, who did indeed find either of the diets suitable, to affect the main outcomes. Our findings indicate that if patients are randomised to an LCD compared with an LFD with resources used to achieve changes in diet composition that are readily available for many providers of care, both diets induce similar weight reductions. This was also in line with the finding that both groups reported similar energy intake during the study. Westman et al have reported more efficient weight reduction with an LCD after 6 months when compared with an LFD [9]. In that study, diet information was facilitated, compared with our design, by lack of energy restriction in the low-carbohydrate group. This could have affected the more beneficial findings compared with our study regarding weight loss. Also, Westman et al had a total of 18 group meetings during their 6 month study, and this could have affected the outcome. Information on increased exercise was also part of their lifestyle change programme, but was not included in ours. Specifically, we aimed to study the effects of macronutrient composition on glycaemic control and cardiovascular risk factors, which was why we aimed to achieve no differences in energy intake in the information we gave to the participants. Interestingly, we did find an increase in HDL-cholesterol after 6 months and a specific reduction in $\mathrm{HbA}_{1 \mathrm{c}}$ levels in the low-carbohydrate group only, which suggests that these effects are dependent on macronutrient composition per se; this is in line with the findings of Westman et al [9].

We also acknowledge that we might have achieved better weight reduction if a design similar to that used in 'Weight Watchers' programmes had been incorporated. For regular care provided by the Swedish tax-based system, incentives used in Weight Watchers, such as public display of the body weight results of the participants, would not be feasible for general use in clinic care because of patient privacy. Also, one should keep in mind that there is selection and incentive in such commercially run programmes, as participants are willing to pay to participate. However, effective weight loss in a Weight Watchers group was recently shown in a study even when the cost for participation was reimbursed by the study organisers [21]. 
Table 3 Completers analysis of anthropometrics, metabolic outcomes and medication in patients with type 2 diabetes randomised to the LFD or LCD who were compliant with energy restriction $<6,694 \mathrm{~kJ} /$ day
(1,600 kcal/day) for women or $<7,531 \mathrm{~kJ} /$ day $(1,800 \mathrm{kcal} /$ day $)$ for men according to diet records at the 24 month registration

\begin{tabular}{|c|c|c|c|c|c|c|c|c|c|c|c|}
\hline \multirow[t]{3}{*}{ Variable } & \multirow[t]{3}{*}{ Diet } & \multicolumn{8}{|c|}{ Time point (months) } & \multirow[t]{3}{*}{$p$ value $^{\mathrm{c}}$} & \multirow[t]{3}{*}{$p$ value $^{\mathrm{d}}$} \\
\hline & & \multicolumn{2}{|l|}{0} & \multicolumn{2}{|l|}{6} & \multicolumn{2}{|l|}{12} & \multicolumn{2}{|l|}{24} & & \\
\hline & & Value & $p$ value $^{\mathrm{a}}$ & Value & $p$ value $^{\mathrm{b}}$ & Value & $p$ value $^{\mathrm{b}}$ & Value & $p$ value $^{\mathrm{b}}$ & & \\
\hline Weight (kg) & $\begin{array}{l}\text { LFD } \\
\text { LCD }\end{array}$ & $\begin{array}{l}90.6 \pm 19 \\
88.0 \pm 16\end{array}$ & 0.66 & $\begin{array}{l}86.7 \pm 19 \\
83.4 \pm 15\end{array}$ & $\begin{array}{l}<0.001 \\
<0.001\end{array}$ & $\begin{array}{l}88.0 \pm 19 \\
85.6 \pm 15\end{array}$ & $\begin{array}{l}<0.001 \\
<0.001\end{array}$ & $\begin{array}{l}87.5 \pm 19 \\
84.4 \pm 16\end{array}$ & $\begin{array}{l}0.008 \\
0.002\end{array}$ & $\begin{array}{l}<0.001 \\
<0.001\end{array}$ & 0.75 \\
\hline BMI $\left(\mathrm{kg} / \mathrm{m}^{2}\right)$ & $\begin{array}{l}\text { LFD } \\
\text { LCD }\end{array}$ & $\begin{array}{l}31.6 \pm 5 \\
31.0 \pm 4.5\end{array}$ & 0.71 & $\begin{array}{l}30.2 \pm 5 \\
29.4 \pm 4.1\end{array}$ & $\begin{array}{l}<0.001 \\
<0.001\end{array}$ & $\begin{array}{l}30.7 \pm 5 \\
30.0 \pm 4.5\end{array}$ & $\begin{array}{l}<0.001 \\
0.001\end{array}$ & $\begin{array}{l}30.5 \pm 5 \\
29.8 \pm 4.5\end{array}$ & $\begin{array}{l}0.005 \\
0.002\end{array}$ & $\begin{array}{l}<0.001 \\
<0.001\end{array}$ & 0.74 \\
\hline Waist (cm) & $\begin{array}{l}\text { LFD } \\
\text { LCD }\end{array}$ & $\begin{array}{l}107 \pm 13 \\
103 \pm 12\end{array}$ & 0.31 & $\begin{array}{l}102 \pm 15 \\
100 \pm 10\end{array}$ & $\begin{array}{l}<0.001 \\
0.004\end{array}$ & $\begin{array}{l}103 \pm 16 \\
100 \pm 10\end{array}$ & $\begin{array}{l}<0.001 \\
0.072\end{array}$ & $\begin{array}{l}103 \pm 16 \\
100 \pm 12\end{array}$ & $\begin{array}{l}0.004 \\
0.003\end{array}$ & $\begin{array}{l}<0.001 \\
0.023\end{array}$ & 0.57 \\
\hline $\begin{array}{l}\text { Sagittal abdominal } \\
\text { diameter }(\mathrm{cm})\end{array}$ & $\begin{array}{l}\text { LFD } \\
\text { LCD }\end{array}$ & $\begin{array}{l}26 \pm 5 \\
26 \pm 4\end{array}$ & 0.97 & $\begin{array}{l}25 \pm 3 \\
25 \pm 3\end{array}$ & $\begin{array}{l}0.58 \\
0.009\end{array}$ & $\begin{array}{l}26 \pm 3 \\
24 \pm 3\end{array}$ & $\begin{array}{l}0.68 \\
0.003\end{array}$ & $\begin{array}{l}26 \pm 4 \\
24 \pm 3\end{array}$ & $\begin{array}{l}0.49 \\
0.016\end{array}$ & $\begin{array}{l}0.46 \\
0.002\end{array}$ & 0.40 \\
\hline $\mathrm{HbA}_{1 \mathrm{c}}(\%)$ & $\begin{array}{l}\text { LFD } \\
\text { LCD }\end{array}$ & $\begin{array}{l}7.4 \pm 2.8 \\
7.5 \pm 2.8\end{array}$ & 0.83 & $\begin{array}{l}7.3 \pm 3.1 \\
7.0 \pm 2.9\end{array}$ & $\begin{array}{l}0.23 \\
0.016\end{array}$ & $\begin{array}{l}7.2 \pm 2.9 \\
7.2 \pm 3.1\end{array}$ & $\begin{array}{l}0.021 \\
0.062\end{array}$ & $\begin{array}{l}7.5 \pm 3.1 \\
7.5 \pm 2.9\end{array}$ & $\begin{array}{l}0.69 \\
0.94\end{array}$ & $\begin{array}{l}0.19 \\
0.026\end{array}$ & 0.73 \\
\hline $\mathrm{HbA}_{1 \mathrm{c}}(\mathrm{mmol} / \mathrm{mol})$ & $\begin{array}{l}\text { LFD } \\
\text { LCD }\end{array}$ & $\begin{array}{l}57.9 \pm 7.6 \\
58.4 \pm 7.5\end{array}$ & 0.83 & $\begin{array}{l}55.9 \pm 9.9 \\
52.8 \pm 8.3\end{array}$ & $\begin{array}{l}0.23 \\
0.016\end{array}$ & $\begin{array}{l}55.5 \pm 8.0 \\
54.8 \pm 10.1\end{array}$ & $\begin{array}{l}0.021 \\
0.062\end{array}$ & $\begin{array}{l}58.5 \pm 10.4 \\
58.3 \pm 8.7\end{array}$ & $\begin{array}{l}0.69 \\
0.94\end{array}$ & $\begin{array}{l}0.19 \\
0.026\end{array}$ & 0.73 \\
\hline $\begin{array}{l}\text { Systolic blood } \\
\text { pressure }(\mathrm{mmHg})\end{array}$ & $\begin{array}{l}\text { LFD } \\
\text { LCD }\end{array}$ & $\begin{array}{l}134 \pm 11 \\
133 \pm 13\end{array}$ & 0.73 & $\begin{array}{l}129 \pm 13 \\
125 \pm 16\end{array}$ & $\begin{array}{l}0.078 \\
0.053\end{array}$ & $\begin{array}{l}127 \pm 12 \\
127 \pm 13\end{array}$ & $\begin{array}{l}0.022 \\
0.085\end{array}$ & $\begin{array}{l}123 \pm 10 \\
126 \pm 14\end{array}$ & $\begin{array}{l}0.005 \\
0.195\end{array}$ & $\begin{array}{l}0.007 \\
0.13\end{array}$ & 0.73 \\
\hline $\begin{array}{l}\text { Diastolic blood } \\
\text { pressure }(\mathrm{mmHg})\end{array}$ & $\begin{array}{l}\text { LFD } \\
\text { LCD }\end{array}$ & $\begin{array}{l}74 \pm 10 \\
74 \pm 11\end{array}$ & 0.91 & $\begin{array}{l}74 \pm 8 \\
71 \pm 8\end{array}$ & $\begin{array}{l}0.84 \\
0.17\end{array}$ & $\begin{array}{l}68 \pm 9 \\
71 \pm 11\end{array}$ & $\begin{array}{l}0.035 \\
0.16\end{array}$ & $\begin{array}{l}70 \pm 8 \\
71 \pm 8\end{array}$ & $\begin{array}{l}0.032 \\
0.11\end{array}$ & $\begin{array}{l}0.012 \\
0.22\end{array}$ & 0.80 \\
\hline $\begin{array}{l}\text { Total cholesterol } \\
(\mathrm{mmol} / \mathrm{l})\end{array}$ & $\begin{array}{l}\text { LFD } \\
\text { LCD }\end{array}$ & $\begin{array}{l}4.0 \pm 0.7 \\
4.5 \pm 1.0\end{array}$ & 0.078 & $\begin{array}{l}4.1 \pm 0.9 \\
4.4 \pm 1.3\end{array}$ & $\begin{array}{l}0.67 \\
0.65\end{array}$ & $\begin{array}{l}4.0 \pm 0.7 \\
4.4 \pm 0.9\end{array}$ & $\begin{array}{l}0.66 \\
0.34\end{array}$ & $\begin{array}{l}3.9 \pm 0.8 \\
4.4 \pm 1.0\end{array}$ & $\begin{array}{l}0.57 \\
0.67\end{array}$ & $\begin{array}{l}0.73 \\
0.90\end{array}$ & 0.11 \\
\hline $\begin{array}{l}\text { LDL-cholesterol } \\
(\mathrm{mmol} / \mathrm{l})\end{array}$ & $\begin{array}{l}\text { LFD } \\
\text { LCD }\end{array}$ & $\begin{array}{l}2.2 \pm 0.4 \\
2.7 \pm 0.9\end{array}$ & 0.043 & $\begin{array}{l}2.2 \pm 0.7 \\
2.5 \pm 0.9\end{array}$ & $\begin{array}{l}0.84 \\
0.37\end{array}$ & $\begin{array}{l}2.2 \pm 0.6 \\
2.5 \pm 0.7\end{array}$ & $\begin{array}{l}0.91 \\
0.10\end{array}$ & $\begin{array}{l}2.0 \pm 0.7 \\
2.4 \pm 0.8\end{array}$ & $\begin{array}{l}0.16 \\
0.066\end{array}$ & $\begin{array}{l}0.43 \\
0.34\end{array}$ & 0.13 \\
\hline $\begin{array}{l}\text { HDL-cholesterol } \\
(\mathrm{mmol} / \mathrm{l})\end{array}$ & $\begin{array}{l}\text { LFD } \\
\text { LCD }\end{array}$ & $\begin{array}{l}1.14 \pm 0.32 \\
1.15 \pm 0.36\end{array}$ & 0.94 & $\begin{array}{l}1.18 \pm 0.32 \\
1.26 \pm 0.48\end{array}$ & $\begin{array}{l}0.28 \\
0.034\end{array}$ & $\begin{array}{l}1.21 \pm 0.26 \\
1.23 \pm 0.38\end{array}$ & $\begin{array}{l}0.029 \\
0.017\end{array}$ & $\begin{array}{l}1.26 \pm 0.34 \\
1.37 \pm 0.46\end{array}$ & $\begin{array}{l}0.050 \\
<0.001\end{array}$ & $\begin{array}{l}0.080 \\
<0.001\end{array}$ & 0.67 \\
\hline $\begin{array}{l}\text { Triacylglycerols } \\
(\mathrm{mmol} / \mathrm{l})\end{array}$ & $\begin{array}{l}\text { LFD } \\
\text { LCD }\end{array}$ & $\begin{array}{l}1.5 \pm 0.7 \\
1.4 \pm 0.6\end{array}$ & 0.88 & $\begin{array}{l}1.4 \pm 0.7 \\
1.4 \pm 1.1\end{array}$ & $\begin{array}{l}0.67 \\
0.97\end{array}$ & $\begin{array}{l}1.4 \pm 0.7 \\
1.4 \pm 0.5\end{array}$ & $\begin{array}{l}0.17 \\
0.84\end{array}$ & $\begin{array}{l}1.6 \pm 1.0 \\
1.5 \pm 0.8\end{array}$ & $\begin{array}{l}0.52 \\
0.56\end{array}$ & $\begin{array}{l}0.49 \\
0.96\end{array}$ & 0.91 \\
\hline $\begin{array}{l}\text { Total insulin } \\
\text { dose (E) }\end{array}$ & $\begin{array}{l}\text { LFD } \\
\text { LCD }\end{array}$ & $\begin{array}{l}32 \pm 41 \\
26 \pm 54\end{array}$ & 0.73 & $\begin{array}{l}30 \pm 37 \\
14 \pm 28\end{array}$ & $\begin{array}{l}0.34 \\
0.13\end{array}$ & $\begin{array}{l}31 \pm 38 \\
16 \pm 33\end{array}$ & $\begin{array}{l}0.73 \\
0.16\end{array}$ & $\begin{array}{l}30 \pm 40 \\
20 \pm 37\end{array}$ & $\begin{array}{l}0.68 \\
0.34\end{array}$ & $\begin{array}{l}0.92 \\
0.12\end{array}$ & 0.38 \\
\hline Metformin (mg) & $\begin{array}{l}\text { LFD } \\
\text { LCD }\end{array}$ & $\begin{array}{l}1,353 \pm 981 \\
1,278 \pm 844\end{array}$ & 0.81 & $\begin{array}{l}1,176 \pm 865 \\
1,444 \pm 784\end{array}$ & $\begin{array}{l}0.27 \\
0.055\end{array}$ & $\begin{array}{l}1,324 \pm 847 \\
1,306 \pm 860\end{array}$ & $\begin{array}{l}0.79 \\
0.85\end{array}$ & $\begin{array}{l}1,265 \pm 903 \\
1,222 \pm 826\end{array}$ & $\begin{array}{l}0.65 \\
0.71\end{array}$ & $\begin{array}{l}0.58 \\
0.37\end{array}$ & 0.90 \\
\hline $\begin{array}{l}\text { Glibenclamide } \\
\text { (mg) }\end{array}$ & $\begin{array}{l}\text { LFD } \\
\text { LCD }\end{array}$ & $\begin{array}{l}0.7 \pm 2.6 \\
1.5 \pm 3.1\end{array}$ & 0.45 & $\begin{array}{l}0.5 \pm 1.7 \\
0.5 \pm 1.2\end{array}$ & $\begin{array}{l}0.33 \\
0.056\end{array}$ & $\begin{array}{l}0.6 \pm 1.7 \\
0.3 \pm 0.9\end{array}$ & $\begin{array}{l}0.67 \\
0.083\end{array}$ & $\begin{array}{l}0.6 \pm 1.7 \\
0.2 \pm 0.8\end{array}$ & $\begin{array}{l}0.67 \\
0.099\end{array}$ & $\begin{array}{l}0.69 \\
0.039\end{array}$ & 1.0 \\
\hline Simvastatin (mg) & $\begin{array}{l}\text { LFD } \\
\text { LCD }\end{array}$ & $\begin{array}{l}21 \pm 17 \\
18 \pm 19\end{array}$ & 0.64 & $\begin{array}{l}21 \pm 17 \\
23 \pm 19\end{array}$ & $\begin{array}{l}-^{\mathrm{e}} \\
0.16\end{array}$ & $\begin{array}{l}25 \pm 17 \\
26 \pm 23\end{array}$ & $\begin{array}{l}0.19 \\
0.049\end{array}$ & $\begin{array}{l}25 \pm 17 \\
26 \pm 23\end{array}$ & $\begin{array}{l}0.19 \\
0.049\end{array}$ & $\begin{array}{l}0.14 \\
0.025\end{array}$ & 0.95 \\
\hline Atorvastatin (mg) & $\begin{array}{l}\text { LFD } \\
\text { LCD }\end{array}$ & $\begin{array}{l}1 \pm 2 \\
3 \pm 7\end{array}$ & 0.21 & $\begin{array}{l}1 \pm 5 \\
3 \pm 8\end{array}$ & $\begin{array}{l}0.33 \\
0.33\end{array}$ & $\begin{array}{l}1 \pm 5 \\
3 \pm 8\end{array}$ & $\begin{array}{l}0.33 \\
0.33\end{array}$ & $\begin{array}{l}1 \pm 5 \\
3 \pm 8\end{array}$ & $\begin{array}{l}0.33 \\
0.33\end{array}$ & $\begin{array}{l}0.40 \\
0.40\end{array}$ & 0.30 \\
\hline
\end{tabular}

LFD, $n=17$; LCD, $n=18$

${ }^{\text {a }}$ Between groups at baseline

${ }^{\mathrm{b}}$ For change compared with baseline

${ }^{\mathrm{c}}$ For change over all time points

${ }^{\mathrm{d}}$ For change over all time points between groups

${ }^{\mathrm{e}}$ As there were no changes in simvastatin doses, the $t$ test is not applicable

Although patients in our study who had been randomised to the low-carbohydrate group reported a lower intake of carbohydrates at baseline compared with the low-fat group, this was unrelated to weight changes in statistical analyses. In retrospect, this group difference in reported intake of macronutrients between the groups might have been a consequence of the participants being informed of the randomisation results before the diet record at baseline was performed. Consequently, some participants may have adjusted their diet to make it similar to that to which they had been allocated, ahead of the first group information meeting. Unfortunately the baseline difference was not elucidated 
until the end of the trial and it was thus judged to be of little meaning to ask participants with little intake of energy from carbohydrates in the low-carbohydrate group at baseline whether this was a consequence of the randomisation, which had occurred more than 2 years earlier.

The largest changes in macronutrient intake were seen in patients randomised to the low-carbohydrate group. Indeed, patients in the low-fat group had the same macronutrient composition at baseline as during the study, suggesting that this was indeed a traditional diet and that they, according to the diet records, had been given similar diet recommendations earlier.

The patients following the LCD increased the percentage of energy intake from both total and saturated fat throughout the 24 months of the trial according to diet records, in line with the study protocol. At 6 months, when weight reduction was most pronounced, only the LCD group had changes in blood lipid levels in the form of increased HDL-cholesterol. However, during the study there had also been changes in lipid-lowering therapy that make these findings inconclusive regarding whether they solely depended on changes in diet. At the end of the trial, several patients had been newly started on lipid-lowering therapy. This is an obvious limitation of our trial from a mechanistic point of view, but it was a consequence of our efforts to limit the resources necessary for the diets to be implemented in regular primary care, to allow the methods to translate easily to real-life application. However, as 3-hydroxy-3-methylglutaryl-coenzyme A reductase inhibitors (statins) mainly affect LDL-cholesterol levels and, as earlier trials have also found that diets high in fat elevate HDL-cholesterol to a greater extent than high-carbohydrate diets in type 2 diabetes $[9,11,16]$, we find it likely that the increase in HDL-cholesterol in our trial was mainly an effect of the change in diet.

We acknowledge that the general applicability of our study results might be limited because of the high participation rate that was achieved. The study nurses had also taken care of the same patients ahead of the study start and when identifying potential participants according to inclusion and exclusion criteria it cannot be excluded that, prior to the study, they might have discharged patients judged not to have been suitable participants for various reasons. Another potential explanation for the high participation rate was that the study protocol was not very time-consuming for the patients as it involved only four group meetings. We also acknowledge the problems with diet records. Although diet records with notebooks and scales can be more detailed and precise than standardised food frequency questionnaires, results from surveys of food intake have low reproducibility and, in particular, there are systematic errors in underreporting energy intake [22]. Thus, total energy intake might not be accurate in our study, but the lowering of $\mathrm{HbA}_{1 \mathrm{c}}$ in only the low-carbohydrate group at 6 months and also differences in HDL-cholesterol changes at similar weight reductions suggest that the groups did indeed change their macronutrient intake differently in our trial.

The analyses of outcome in the participants who were compliant with either energy intake or with the $\mathrm{E} \%$ from fat implied better long-term effects on weight loss than in the total cohort analysed on an intention-to-treat basis. Although this was a post-hoc analysis, and thus data should be interpreted with caution, it was of interest to note that HDL-cholesterol increased by $33 \%$ in patients reasonably compliant with fat intake, which was in line with data from Westman et al [9]. However, blood pressure levels were not reduced in patients on the LCD at 24 months. It cannot be excluded that salt intake increased in parallel with ingestion of fat, as has been demonstrated in the general population [23], leading to less favourable blood pressure levels. Unfortunately, we did not collect urine for determination of the amount of sodium.

In conclusion, our findings support the use of an LCD with $20 \mathrm{E} \%$ from carbohydrates as an alternative to a traditional low-fat diet, if the aim primarily is to improve glycaemic control in type 2 diabetes. We achieved a weight loss of about $4 \mathrm{~kg}$ in both groups after 6 months based on group information on three occasions and there was only one more group meeting, which took place at 12 months' study duration. However, as in many earlier studies, compliance with the LCD was reduced after 6 months, as judged by the increase in body weight and according to food records, and it cannot be ruled out that different results could have been obtained if more effort had been made to achieve compliance with the diet composition and reduction of energy intake.

Acknowledgements We are grateful for the skilful care of the patients throughout the study by the nurses C. E. Andersson (Borensberg Primary Care Health Centre, Sweden), M. Arnemyr and B. Böttinger (Marieberg Primary Care Health Centre in Motala, Sweden).

Funding The study was supported by University Hospital of Linköping Research Funds, Linköping University, the County Council of Östergötland, and the Diabetes Research Centre of Linköping University.

Duality of interest The authors declare that there is no duality of interest associated with this manuscript.

Contribution statement $\mathrm{HG}$ did the pilot study and came up with the study idea, ran the study and wrote the manuscript. BD, BB and MB-L collected and researched data and reviewed the manuscript. TL and CJÖ participated in the design of the study, researched data and reviewed the manuscript. MF participated in the design of the study, analysis of data and had a particular responsibility for statistical evaluations and writing this part of the manuscript. FHN designed the study with HG, researched data and wrote/edited the manuscript. All authors approved the final version of the manuscript. 
Open Access This article is distributed under the terms of the Creative Commons Attribution License which permits any use, distribution, and reproduction in any medium, provided the original author(s) and the source are credited.

\section{References}

1. Wing RR, Lang W, Wadden TA et al (2011) Benefits of modest weight loss in improving cardiovascular risk factors in overweight and obese individuals with type 2 diabetes. Diabetes Care 34:1481-1486

2. Lavie CJ, Milani RV, Ventura HO (2009) Obesity and cardiovascular disease: risk factor, paradox, and impact of weight loss. J Am Coll Cardiol 53:1925-1932

3. Becker W, Lyhne N, Pedersen AN et al (2004) Nordic nutrition recommendations 2004 - integrating nutrition and physical activity. Scand J Nutr 48:178-187

4. Margetts B (2003) FAO/WHO launch expert report on diet, nutrition and prevention of chronic diseases. Public Health Nutr 6:323-325

5. Bantle JP, Wylie-Rosett J, Albright AL et al (2008) Nutrition recommendations and interventions for diabetes: a position statement of the American Diabetes Association. Diabetes Care 31 (Suppl 1):S61-S78

6. Shai I, Schwarzfuchs D, Henkin Y et al (2008) Weight loss with a low-carbohydrate, Mediterranean, or low-fat diet. N Engl J Med 359:229-241

7. Leosdottir M, Nilsson PM, Nilsson JA, Mansson H, Berglund G (2005) Dietary fat intake and early mortality patterns - data from The Malmo Diet and Cancer Study. J Intern Med 258:153-165

8. Leosdottir M, Nilsson PM, Nilsson JA, Berglund G (2007) Cardiovascular event risk in relation to dietary fat intake in middleaged individuals: data from The Malmo Diet and Cancer Study. Eur J Cardiovasc Prev Rehabil 14:701-706

9. Westman EC, Yancy WS Jr, Mavropoulos JC, Marquart M, McDuffie JR (2008) The effect of a low-carbohydrate, ketogenic diet versus a low-glycemic index diet on glycemic control in type 2 diabetes mellitus. Nutr Metab (Lond) 5:36

10. Iqbal N, Vetter ML, Moore RH et al (2010) Effects of a low-intensity intervention that prescribed a low-carbohydrate vs. a low-fat diet in obese, diabetic participants. Obesity (Silver Spring) 18:1733-1738

11. Elhayany A, Lustman A, Abel R, Attal-Singer J, Vinker S (2010) A low carbohydrate Mediterranean diet improves cardiovascular risk factors and diabetes control among overweight patients with type 2 diabetes mellitus: a 1-year prospective randomized intervention study. Diabetes Obes Metab 12:204-209

12. Daly ME, Paisey R, Millward BA et al (2006) Short-term effects of severe dietary carbohydrate-restriction advice in type 2 diabetesa randomized controlled trial. Diabet Med 23:15-20

13. Nielsen JV, Joensson EA (2008) Low-carbohydrate diet in type 2 diabetes: stable improvement of bodyweight and glycemic control during 44 months follow-up. Nutr Metab (Lond) 5:14

14. Dashti HM, Mathew TC, Khadada M et al (2007) Beneficial effects of ketogenic diet in obese diabetic subjects. Mol Cell Biochem 302:249-256

15. Boden G, Sargrad K, Homko C, Mozzoli M, Stein TP (2005) Effect of a low-carbohydrate diet on appetite, blood glucose levels, and insulin resistance in obese patients with type 2 diabetes. Ann Intern Med 142:403-411

16. Davis NJ, Tomuta N, Schechter C et al (2009) Comparative study of the effects of a 1-year dietary intervention of a low-carbohydrate diet versus a low-fat diet on weight and glycemic control in type 2 diabetes. Diabetes Care 32:1147-1152

17. Sasakabe T, Haimoto H, Umegaki H, Wakai K (2011) Effects of a moderate low-carbohydrate diet on preferential abdominal fat loss and cardiovascular risk factors in patients with type 2 diabetes. Diabetes Metab Syndr Obes 4:167-174

18. Foster GD, Wyatt HR, Hill JO et al (2003) A randomized trial of a low-carbohydrate diet for obesity. N Engl J Med 348:2082-2090

19. Brehm BJ, Seeley RJ, Daniels SR, D’Alessio DA (2003) A randomized trial comparing a very low carbohydrate diet and a calorie-restricted low fat diet on body weight and cardiovascular risk factors in healthy women. J Clin Endocrinol Metab 88:16171623

20. Baron JA, Schori A, Crow B, Carter R, Mann JI (1986) A randomized controlled trial of low carbohydrate and low fat/high fiber diets for weight loss. Am J Public Health 76:1293-1296

21. Jolly K, Lewis A, Beach J et al (2011) Comparison of range of commercial or primary care led weight reduction programmes with minimal intervention control for weight loss in obesity: lighten up randomised controlled trial. BMJ 343:d6500

22. Lof M, Forsum E (2004) Validation of energy intake by dietary recall against different methods to assess energy expenditure. J Hum Nutr Diet 17:471-480

23. Gibson S, Ashwell M (2011) Dietary patterns among British adults: compatibility with dietary guidelines for salt/sodium, fat, saturated fat and sugars. Public Health Nutr 14:1323-1336 